\title{
Teknik dan Kualitas Penerjemahan Frasa Washfi pada Novel Zeina Karya Nawal El Sadawi
}

\author{
${ }^{1}$ Aditya Prayogo, ${ }^{2}$ Fitria Sari Yunianti \\ 1Aditya1700028019@webmail.uad.ac.id,2fitria.yunainti@bsa.uad.ac.id \\ Universitas Ahmad Dahlan, Universitas Ahmad Dahlan
}

\begin{tabular}{ll} 
ARTICLE INFO & ABSTRACT \\
\hline & $\begin{array}{l}\text { This research explain the techniques and quality assessment of the } \\
\text { translation of washfi phrases in the novel Zeina's translation by }\end{array}$ \\
Article history & Nawal El Saadawi. This research is a part of translation criticism by \\
Submitted: & using the descriptive analysis method. This research uses a \\
$22-01-2021$ & qualitative approach in analyzing translation techniques by \\
Accepted: & applying Newmark's theory of translation techniques. In addition, a \\
$20-03-2021$ & quantitative approach is also used in assessing the quality of \\
& translation by applying the theory of translation quality assessment \\
Keywords & by Nababan.
\end{tabular}

quality assessment of the translation, washfi phrases

novel Zeina

The results of this research indicate that there are 348 data on Nawal El Saadawi washfi phrases in the novel Zeina and 40 data on washfi phrases in this study. The techniques used in translation are 10 of 16 Newmark translation techniques. The ten techniques are literal translation technique, transference, reduction, expansion, transposition, synonymy, modulation, naturalization, paraphrasing, and recognized translation technique. As for the assessment of translation quality, the most acceptable translation qualities were literal translation techniques and synonymy techniques (77\%). Meanwhile, the lowest acceptance quality was naturalization technique, which was $62 \%$. Then, the quality of easy / high readability is in the paraphrasing technique, which is $76 \%$. While the quality of the lowest readability is naturalization technique, which is $46 \%$.

This is an open access article under the CC-BY-SA license.

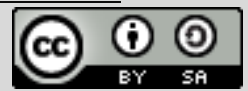

\section{Pendahuluan}

Dewasa ini, dunia penerjemahan telah banyak memberikan kontribusi dalam memperkaya khazanah pengetahuan dunia. Berbagai buku-buku ilmiah maupun buku-buku sastra seperti novel, cerpen, drama maupun karya-karya lainnya telah diterjemahkan ke dalam berbagai bahasa. Hal ini tentunya sangat membantu dalam memahami karya-karya, tulisan-tulisan ataupun pemikiran-pemikiran tokoh-tokoh dunia. 
Penerjemahan merupakan suatu ilmu yang tidak bisa dihilangkan dalam segala aspek kehidupan manusia ${ }^{1}$. Untuk mendapatkan hasil terjemahan yang baik, diperlukan teknik penerjemahan yang tepat. Salah satu teknik penerjemahan yang digagas oleh salah satu pakar penerjemahan adalah yang ditawarkan oleh Newmark, sebagai berikut.

1. Terjemahan harfiah atau literal translation adalah teknik yang menerjemahkan kata demi kata, frasa demi frasa, dan kalimat demi kalimat sesuai dengan struktur bahasa sasaran.

2. Transferensi, yaitu suatu teknik pentransferan kata dalam bahasa sumber ke dalam bahasa sasaran untuk menghasilkan kata pinjaman.

3. Naturalisasi, yaitu membentuk kata baru dalam bahasa dengan cara mengambil bunyi dalam bahasa sumber.

4. Padanan budaya, yaitu teknik mengganti unsur budaya pada bahasa sumber dengan unsur budaya yang dikenal pada bahasa sasaran.

5. Padanan fungsional, yaitu teknik yang menggunakan kata netral secara budaya dan menggunakan istilah yang lebih spesifik.

6. Padanan deskriptif, yaitu teknik yang memberikan uraian yang berisi makna kata atau fungsi kata tersebut.

7. Sinonimi, yaitu teknik yang menggunakan kata-kata yang memiliki arti mendekati dalam bahasa sumber, karena tidak ada kata yang memiliki makna yang sepadan dalam bahasa sasaran.

8. Terjemahan langsung, yaitu teknik penerjemahan harfiah dari kolokasi-kolokasi umum, nama organisasi, atau komponen-komponen senyawa yang sudah di akui.

9. Transposisi, yaitu teknik yang mengubah bentuk gramatikal bahasa sumber kedalam bahasa sasaran.

10. Modulasi, yaitu teknik yang memberikan padanan yang berbeda sudut pandang, perspektif maupun menyangkut perubahan maknawi yang lain secara semantik.

11. Label terjemahan, yaitu terjemahan sementara, biasanya karena ada istilah baru dan terjemahan literal juga bisa diterima dalam memahamkan bahasa sumber ke dalam bahasa sasaran.

12. Terjemahan lazim, yaitu teknik penerjemahan yang memberikan sebuah istilah yang sudah lazim digunakan baik dalam kamus maupun bahasa sasaran sebagai padanan dari teks bahasa sumber.

${ }^{1}$ Romadhan, Mahyudin, and Muhammad Yunus Anis, "RAGAM TEKNIK PENERJEMAHAN FRASA NOMINA DALAM NOVEL MAWĀKIBUL-ACHRĀR KARYA AL-KAILANI: SEBUAH PENDEKATAN TEORI ILMU PENERJEMAHAN ARAB," Jurnal CMES 9, no. 1 (2016): 74. 
13. Kompensasi, yaitu teknik penerjemahan yang memperkenalkan unsur-unsur informasi atau stilistik suatu bahasa sumber ke dalam bahasa sasaran.

14. Reduksi dan ekspansi, reduksi merupakan teknik pengurangan kata-kata dalam bahasa sumber, karena tanpa kata tersebut makna yang yang terkandung dalam bahasa sumber sudah dapat dipahami. Dan ekspansi adalah penambahan kata-kata tertentu dalam suatu teks terjemahan untuk menyampaikan pesan singkat bagi pembaca atau untuk menyampaikan konsep yang ada pada bahasa sumber kepada pembaca.

15. Parafrase, yaitu teknik yang memberikan penjelasan tambahan atau makna lebih detail yang tidak terdapat pada Bahasa sumber².

Bidang lain dalam penerjemahan yang sangat penting untuk diperhatikan juga adalah penilaian kualitas terjemahan. Penilaian kualitas terjemahan sangatlah penting didasarkan pada dua hal yaitu, untuk meciptakan hubungan dialektik antara teori dan praktik penerjemahan, dan untuk kepentingan penilaian standar dan kriteria dalam menilai kompetensi penerjemahan, terutama dalam menilai beberapa versi teks Bsa dari teks Bsu yang sama ${ }^{3}$. Nababan berpendapat bahwa terjemahan yang berkualitas adalah terjemahan yang akurat dari segi isi teks terjemahan, teks terjemahan diungkapkan dengan kaidah-kaidah yang berlaku pada bahasa sasaran dan tidak bertentangan dengan norma dan budaya yang berlaku pada bahasa sasaran, serta terjemahan dapat dipahami dengan mudah oleh pembaca bahasa sasaran ${ }^{4}$. Kualitas terjemahan ditentukan oleh tiga aspek yaitu keakuratan, keberterimaan dan keterbacaan. Namun peneltian ini hanya akan menekankan pada kualitas keberterimaan dan keterbacaan pada terjemahan novel Zeina karya Nawal El Saadawi menggunakan teori yang ditawarkan oleh Nababan.

Untuk menilai keberterimaan hasil terjemahan, ada tiga instrument yang digunakan untuk mengukurnya, yaitu:

\begin{tabular}{|l|l|l|}
\hline Kategori terjemahan & Skor & \multicolumn{1}{c|}{ Indikator } \\
\hline Berterima & 3 & $\begin{array}{l}\text { Terjemahan terasa alami dan sudah sesuai dengan } \\
\text { kaidah dan budaya bahasa sasaran. }\end{array}$ \\
\hline Kurang berterima & 2 & $\begin{array}{l}\text { Terjemahan kurang terasa alami, karena terdapat } \\
\text { beberapa bagian yang tidak sesuai dengan kaidah dan } \\
\text { budaya bahasa sasaran. }\end{array}$ \\
\hline Tidak berterima & 1 & $\begin{array}{l}\text { Terjemahan sama sekali tidak alami, tidak sesuai } \\
\text { dengan kaidah dan budaya bahasa sasaran. }\end{array}$ \\
\hline
\end{tabular}

${ }^{2}$ Newmark, Peter, A Textbook of Translation (New York: Prentice Hall International vUIO Ltd, 1988), 81-90.

${ }^{3}$ Machali, Rochayal, Pedoman Bagi Penerjemah (Jakarta: Grasindo, 2000), 108.

${ }^{4}$ Nababan, Mangatur, and Ardiana Nuraeni., "Pengembangan model penilaian kualitas terjemahan," Kajian Linguistik dan Sastra 24, no. 1 (2012): 41. 
Sedangkan untuk mengukur kualitas keterbacaan hasil terjemahan, indicator yang digunakan adalah sebagai berikut:

a. Instrumen penilaian kualitas keterbacaan

\begin{tabular}{|l|l|l|}
\hline Kategori terjemahan & \multicolumn{1}{|c|}{ Skor } & \multicolumn{1}{c|}{ Indikator } \\
\hline Mudah & 3 & Terjemahan mudah dipahami oleh pembaca. \\
\hline Sedang & 2 & $\begin{array}{l}\text { Terjemahan dapat dipahami oleh pembaca, namun } \\
\text { ada beberapa bagian yang perlu dibaca lebih dari satu } \\
\text { kali untuk memahami terjemahan. }\end{array}$ \\
\hline Sulit & 1 & Terjemahan sulit dipahami oleh pembaca \\
\hline
\end{tabular}

\section{Metode Penelitian}

Penelitian ini merupakan library research di mana peneliti memperoleh data penelitiannya lewat buku-buku atau sumber informasi pustaka lainnya ${ }^{5}$. Beberapa tahap pengumpulan dan Analisa data dipaparkan sebagai berikut. Pertama, untuk teknik penerjemahamn, pengumpulan data frasa washfi pada Novel Zeina dan terjemahannya dalam Bahasa Indonesia. Kedua, membandingkan Bahasa sumber dan Bahasa sasaran serta menganalisanya menggunakan teknik penerjemahan Newmark. Selanjutnya, untuk penilaian kualitas terjemahan, kuisioner diberikan kepada 25 responden. Adapun kriteria responden dalam penelitian ini adalah:

1) Mahasiswa dan alumni bahasa dan sasra Arab/pendidikan bahasa Arab.

2) Mahasiswa dengan minimal semester 5 .

3) Sudah mengambil mata kuliah teori terjemahan.

4) Sudah mengambil/menguasai ilmu nahwu dan sharaf dengan baik.

5) Menguasai bahasa Indonesia dan Arab dengan baik.

Hasil kuisioner dianalis menggunakan teori evaluasi penerjemahan oleh Nababan.

\section{Diskusi}

\section{Teknik penerjemahan Frasa Washfi pada Novel Zeina}

Ada 40 sample frasa Washfi dalam novel Zeina yang menggunakan 10 teknik penerjemahan Newmark. Adapun rinciannya sebagai berikut

\section{A. Teknik Penerjemahan Harfiah}

Terjemahan harfiah atau literal translation adalah teknik yang menerjemahkan kata demi kata, frasa demi frasa, dan kalimat demi kalimat sesuai dengan struktur bahasa sasaran. Berikut merupakan penerjemahan yang menggunakan teknik harfiah :

${ }^{5}$ Zaim, Muhammad, Metode penelitian bahasa: Pendekatan struktural. (Padang: FBS UNP Press, 2014), 18. 
1. (Data 1)

\begin{tabular}{|l|c|c|c|}
\hline \multicolumn{1}{|c|}{ Bahasa sasaran } & Hal/baris & Bahasa sumber & Hal/baris \\
\hline $\begin{array}{l}\text { Aku adalah putri guru } \\
\text { besar Zakaria al Khartiti. }\end{array}$ & $1 / 8$ & فأنا ابنة الأستاذ الكبير زكريا الخرتيتي & $7 / 4$ \\
\hline
\end{tabular}

Konstruksi frasa washfi di atas, menggunakan teknik penerjemahan harfiah. Seperti yang telah tertera dalam kamus, kata الأستاذ berarti "guru"6 dan kata الكبير berarti “besar"7. الأستاذ adalah "guru besar".

2. (Data 2)

\begin{tabular}{|l|c|r|c|}
\hline \multicolumn{1}{|c|}{ Bahasa sasaran } & Hal/baris & Bahasa sumber & Hal/baris \\
\hline $\begin{array}{l}\text { Ruangan besar dengan } \\
\text { empat dinding yang di } \\
\text { tutupi oleh rak buku. }\end{array}$ & $7 / 6$ & غرفة كبيرة جدراغا الأربعة تغطيها & $11 / 17$ \\
\hline رفوف الكتبا & & \\
\hline
\end{tabular}

Konstruksi frasa washfi di atas, menggunakan teknik penerjemahan harfiah. Seperti yang telah tertera dalam kamus, kata غرفة berarti "ruangan"8 dan kata كبيرة berarti "besar"9. غرفة Oleh karena itu jika diterjemahkan secara berurutan maka frasa nomina washfi dari كبيرة adalah "ruangan besar".

3. (Data 3)

\begin{tabular}{|l|c|r|c|}
\hline \multicolumn{1}{|c|}{ Bahasa sasaran } & Hal/baris & Bahasa sumber & Hal/baris \\
\hline $\begin{array}{l}\text { Atau salah satu puisi yang } \\
\text { rendah maknanya tentang } \\
\text { kecintaan politik. }\end{array}$ & $59 / 13$ & أو قصيدة ركيكة من قصائده في & الغزل السياسي \\
\hline
\end{tabular}

${ }^{6}$ Warson, Ahmad Munawwir, Al-Munawwir: Kamus Arab-Indonesia (Surabaya: Pustaka Progresif, 1997), 967.

7 Warson, Ahmad Munawwir, 1184.

8 Warson, Ahmad Munawwir, 1003.

${ }_{9}^{9}$ Warson, Ahmad Munawwir, 1184. 
Dari penerjemahan di atas, penerjemah menggunakan teknik penerjemahan harfiah atau literal translation, yaitu penerjemah mengalih bahasakan Bsu ke dalam Bsa secara قصيدة harfiah sesuai dengan struktur Bsa. Seperti yang telah tertera dalam kamus, kata berarti "puisi"10 dan kata ركيكة berarti "rendah maknanya"11. Oleh karena itu jika diterjemahkan secara berurutan maka frasa nomina washfi dari قصيدة ركيكة adalah "puisi yang rendah maknanya ".

4. (Data 4)

\begin{tabular}{|c|c|c|c|}
\hline Bahasa sasaran & Hal/baris & Bahasa sumber & Hal/baris \\
\hline $\begin{array}{l}\text { Laki-laki, perempuan, } \\
\text { pemuda, dan anak-anak. } \\
\text { Mereka keluar dari lorong- } \\
\text { lorong, gang-gang, dan } \\
\text { jalan-jalan besar. }\end{array}$ & $19 / 4$ & نساء ورجال وشباب وأطفال، من & $21 / 2$ \\
\hline
\end{tabular}

Konstruksi frasa washfi di atas, menggunakan teknik penerjemahan harfiah. Seperti yang telah tertera dalam kamus, kata الشوارع berarti “jalan-jalan12” dan kata الكبيرة berarti "besar"13. Oleh karena itu jika diterjemahkan secara berurutan maka frasa nomina washfi dari الشوارع الكبيرة adalah “jalan-jalan besar”.

5. (Data 5)

\begin{tabular}{|l|c|c|c|}
\hline \multicolumn{1}{|c|}{ Bahasa sasaran } & Hal/baris & Bahasa sumber & Hal/baris \\
\hline $\begin{array}{l}\text { Tawa keras dari waktu } \\
\text { ke waktu. }\end{array}$ & $54 / 11$ & تطلق ضحكة عالية من حين إلى حين & \\
\hline
\end{tabular}

Konstruksi frasa washfi di atas, menggunakan teknik penerjemahan harfiah. Seperti yang telah tertera dalam kamus, kata ضحكة berarti “Tawa"14 dan kata عالية berarti

10 Warson, Ahmad Munawwir, 1124.

11 Warson, Ahmad Munawwir, 529.

12 Warson, Ahmad Munawwir, 712.

13 Warson, Ahmad Munawwir, 1184.

14 Warson, Ahmad Munawwir, 813. 
"(suara) yang keras"15. Oleh karena itu jika diterjemahkan secara berurutan maka frasa nomina washfi dari ضحكة عالية adalah "tawa keras”.

\section{B. Teknik Transferensi}

Transferensi (loan word), yaitu suatu teknik pentransferan kata dalam bahasa sumber ke dalam bahasa sasaran untuk menghasilkan kata pinjaman. Berikut adalah data yang menggunakan teknik transferensi :

Transferensi (loan word), yaitu suatu teknik pentransferan kata dalam bahasa sumber ke dalam bahasa sasaran untuk menghasilkan kata pinjaman. Berikut adalah data yang menggunakan teknik transferensi :

1. (Data 6)

\begin{tabular}{|l|c|c|c|}
\hline \multicolumn{1}{|c|}{ Bahasa sasaran } & Hal/baris & Bahasa sumber & Hal/baris \\
\hline $\begin{array}{l}\text { Ia sholat jumat di belakang } \\
\text { shaf pertama. }\end{array}$ & $58 / 13$ & $\underline{\text { يصلي الجمعة وراء الصف الأول }}$ & \\
\hline
\end{tabular}

Kata الأول secara harfiah berarti "barisan"16 dan kata "pertama"17.

Sehingga berarti "barisan pertama". Namun oleh penerjemah, Kata الصف diterjemahkan menjadi "shaf" bukan "barisan". Sehingga penerjemah menggunakan teknik transferensi, yaitu mentransferan kata dalam bahasa sumber ke dalam bahasa sasaran sebagai kata pinjaman.

2. (Data 7)

\begin{tabular}{|c|c|c|c|}
\hline Bahasa sasaran & Hal/baris & Bahasa sumber & Hal/baris \\
\hline $\begin{array}{l}\text { Ia mencium Hajar aswad } \\
\text { denngan kedua bibirnya. }\end{array}$ & $364 / 12$ & قبَّل الحجر الأسود بشفتيه & $300 / 12$ \\
\hline
\end{tabular}

Frasa washfi الحجر الأسود smerupakan nama sebuah batu yang diyakini oleh umat

Islam berasal dari surga dan berada di dekat ka'bah. Secara harfiah kata الحجر berarti

15 Warson, Ahmad Munawwir, 969.

16 Warson, Ahmad Munawwir, 782.

17 Warson, Ahmad Munawwir, 49. 
"batu”18 dan kata الأسود berarti "hitam"19. Sehingga jika diurutkan maka berarti "batu yang

hitam". Namun oleh penerjemah frasa tersebut diterjemahkan menjadi "Hajar Aswad". penerjemah menggunakan teknik transferensi pada frasa tersebut, dengan mentransfer kata dalam bahasa sumber ke dalam bahasa sasaran sebagai kata pinjaman.

3. (Data 8)

\begin{tabular}{|c|c|c|c|}
\hline Bahasa sasaran & Hal/baris & Bahasa sumber & Hal/baris \\
\hline $\begin{array}{l}\text { Terkadang ia kencing di } \\
\text { kasurnya karena takut jatuh } \\
\text { dari shiratal mustaqim } \\
\text { setelah kematian. }\end{array}$ & $235 / 13$ & وتبول في فراشها أحيانا خوف من أن تمون من فوق الصراط المستقيم & $196 / 15$ \\
\hline
\end{tabular}

Frasa washfi الصراط المستقيم secara harfiah berarti “jalan yang lurus". Namun oleh penerjemah frasa tersebut diterjemahkan menjadi "shiratal mustaqim". Sehingga penerjemah menggunakan teknik transferensi pada frasa tersebut, dengan mentransfer kata dalam bahasa sumber ke dalam bahasa sasaran sebagai kata pinjaman.

4. (Data 9)

\begin{tabular}{|l|c|c|c|}
\hline \multicolumn{1}{|c|}{ Bahasa sasaran } & Hal/baris & Bahasa sumber & Hal/baris \\
\hline $\begin{array}{l}\text { Ia akan menghapus apa } \\
\text { yang tertulis di lauhul } \\
\text { mahfuz sejak sebelum lahir. }\end{array}$ & $358 / 18$ & هوف تمسح من فوق جبينها ما موتوب في اللوح المحفوظ قبل & \\
\hline & & & \\
& & & \\
\hline
\end{tabular}

Dari penerjemahan di atas, secara harfiah kata المفوظ berarti "papan"20 dan kata اللوح

berarti "dijaga"21. Namun oleh penerjemah frasa tersebut diterjemahkan menjadi "shiratal mustaqim". Sehingga penerjemah menggunakan teknik transferensi pada frasa tersebut, dengan mentransfer kata-kata dalam bahasa sumber ke dalam bahasa sasaran sebagai kata pinjaman.

18 Warson, Ahmad Munawwir, 238.

19 Warson, Ahmad Munawwir, 676.

20 Warson, Ahmad Munawwir, 1295.

21 Warson, Ahmad Munawwir, 279. 
5. (Data 10)

\begin{tabular}{|c|c|c|c|}
\hline Bahasa sasaran & Hal/baris & Bahasa sumber & Hal/baris \\
\hline $\begin{array}{l}\text { Hanya Maryam si gadis, ibu } \\
\text { Nabi Isa Almasih. }\end{array}$ & $201 / 16$ & فقط مريم العذراء أم سيدنا عيسى & $169 / 12$ \\
\hline
\end{tabular}

Dari penerjemahan di atas, kata عيسى merupakan nama dari "Nabi isa" dan kata المسيح merupakan "gelar nabi Isa"22. Namun oleh penerjemah frasa tersebut diterjemahkan menjadi “Isa Almasih". Sehingga kata المسيح merupakan kata yang ditransfer dari bahasa sumber ke dalam bahasa sasaran sebagai kata pinjaman.

\section{Teknik Reduksi}

Teknik reduksi merupakan teknik pengurangan kata-kata dalam bahasa sumber, karena tanpa kata tersebut makna yang yang terkandung dalam bahasa sumber sudah dapat dipahami. Berikut merupakan terjemahan yang menggunakan teknik reduksi :

1. (Data 11)

\begin{tabular}{|l|c|c|c|}
\hline \multicolumn{1}{|c|}{ Bahasa sasaran } & Hal/baris & Bahasa sumber & Hal/baris \\
\hline $\begin{array}{l}\text { Paras wajahnya } \\
\text { melubangi otakku, dalam } \\
\text { tulang kepala dan pikiran. }\end{array}$ & $1 / 2$ & مالاعها مخفورة في خلايا المخخ, داخل الرأس وسراديب العقل الباطن & $7 / 2$ \\
\hline
\end{tabular}

Kata الباطن dalam kamus berarti "pikiran"23 dan kata "yang samar/tersembunyi"24. Sehingga secara harfiah frasa washfi العقل الباطن berarti "pikiran yang samar/tersembunyi”. Namun oleh penerjemah, diterjemahkan ke dalam BSa menjadi "pikiran” saja. Sehingga kata الباطن yang berarti "yang samar/tersembunyi” merupakan kata yang direduksi dalam penerjemahan tersebut.

22 Warson, Ahmad Munawwir, 1333.

23 Warson, Ahmad Munawwir, 967.

${ }^{24}$ Warson, Ahmad Munawwir, 93. 
2. (Data 12)

\begin{tabular}{|l|c|c|c|}
\hline \multicolumn{1}{|c|}{ Bahasa sasaran } & Hal/baris & Bahasa sumber & Hal/baris \\
\hline $\begin{array}{l}\text { Suaminya berbicara } \\
\text { menyindir. }\end{array}$ & $112 / 10$ & يخاطبها زوجها بلهجة ساخرة & 96/13 \\
\hline
\end{tabular}

Kata dalam kamus berarti "dialek/aksen"25 dan kata ساخرة berarti "menyindir"26.

Sehingga secara harfiah frasa washfi لفجة ساخرة berarti “dialek yang menyindir”. Naumun

oleh penerjemah, kata لهجة yang berarti “dialek/aksen” direduksi dalam penerjemahan tersebut. Karena tanpa adanya kata tersebut makna yang terkandung dalam bahasa sumber sudah dapat dipahami.

3. (Data 13)

\begin{tabular}{|c|c|c|c|}
\hline Bahasa sasaran & Hal/baris & Bahasa sumber & Hal/baris \\
\hline $\begin{array}{l}\text { Zeina binti Zeinat tidak } \\
\text { memiliki ijazah. }\end{array}$ & $231 / 21$ & 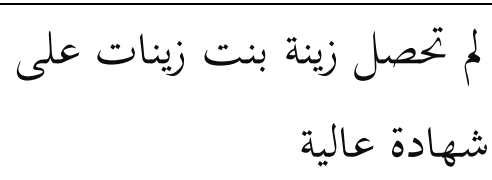 & $193 / 16$ \\
\hline
\end{tabular}

Kata شهادة dalam kamus berarti “ijazah"27 dan kata عالية berarti “tinggi”28. Sehingga secara harfiah frasa washfi شهادة عالية berarti “ijazah tinggi”. Namun oleh penerjemah, kata عالية yang berarti "tinggi" direduksi dalam penerjemahan tersebut. Karena tanpa adanya kata tersebut makna yang terkandung dalam bahasa sumber sudah dapat dipahami.

4. (Data 14)

\begin{tabular}{|c|c|c|c|}
\hline Bahasa sasaran & Hal/baris & Bahasa sumber & Hal/baris \\
\hline $\begin{array}{l}\text { Ia digigit oleh nyamuk } \\
\text { yang berputar di } \\
\text { kepalanya sebelum tidur. }\end{array}$ & $316 / 18$ & لسعته بعوضة عنيدة كانت تزن & $262 / 1$ \\
\hline
\end{tabular}

25 Warson, Ahmad Munawwir, 1291.

26 Warson, Ahmad Munawwir, 618.

27 Warson, Ahmad Munawwir, 747.

28 Warson, Ahmad Munawwir, 969. 
Kata بعوضة dalam kamus berarti "nyamuk"29 dan kata عنيدة berarti "keras kepala"30.

Sehingga secara harfiah frasa washfi بعوضة عنيدة berarti "nyamuk yang keras kepala".

Namun oleh penerjemah, kata عنيدة berarti "keras kepala” direduksi dalam penerjemahan tersebut agar penerjemahan ke dalam BSa lebih berterima dan mudah dipahami oleh pembaca.

5. (Data 15)

\begin{tabular}{|l|c|c|c|}
\hline \multicolumn{1}{|c|}{ Bahasa sasaran } & Hal/baris & Bahasa sumber & Hal/baris \\
\hline $\begin{array}{l}\text { Ia digigit oleh nyamuk } \\
\text { yang berputar di } \\
\text { kepalanya sebelum tidur. }\end{array}$ & $87 / 2$ & يتعمد الخرتيتي أن يشخط في & $101 / 19$ \\
& & الصحفي بصوت عال خشن & \\
\hline
\end{tabular}

Kata عوت dalam kamus berarti "suara"31 dan kata عال berarti "yang keras"32, serta kata خشن berarti “yang keras”. Sehingga secara harfiah frasa washfi

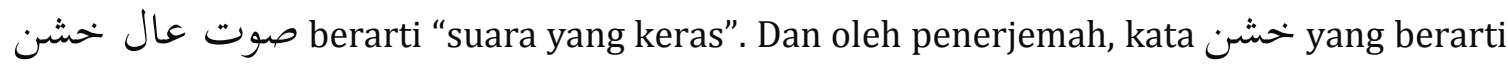
"yang keras" direduksi dalam penerjemahan tersebut. Karena kata خشن dan kata عال memiliki arti yang sama. Sehingga penerjemahan tersebut dapat lebih berterima maupun terbaca pada BSa.

\section{Teknik Ekspansi}

Teknik ekspansi merupakan teknik penambahan kata-kata tertentu dalam suatu teks untuk menyampaikan pesan singkat bagi pembaca atau untuk menyampaikan konsep yang ada pada bahasa sumber kepada pembaca. merupakan terjemahan yang menggunakan teknik ekspansi :

${ }^{29}$ Warson, Ahmad Munawwir, 95.

30 Warson, Ahmad Munawwir, 977.

31 Warson, Ahmad Munawwir, 801.

32 Warson, Ahmad Munawwir, 969. 
1. (Data 16)

\begin{tabular}{|c|c|c|c|}
\hline Bahasa sasaran & Hal/baris & Bahasa sumber & Hal/baris \\
\hline $\begin{array}{l}\text { Saat mudanya } \\
\text { gerakannya lambat } \\
\text { dengan senyum kecil di } \\
\text { wajahnya. }\end{array}$ & $122 / 5$ & ابتيي الشباب بحركة بطيئة من رأسه مع & $104 / 4$ \\
\hline
\end{tabular}

Penerjemahan di atas menggunakan teknik ekspansi. Dapat dilihat bahwa frasa washfi diterjemahkan menjadi "senyum kecil di wajahnya". Kata ابتسامة dalam kamus berarti "senyum"33 dan kata صغيرة berarti "kecil"34. Dan secara harfiah berarti "senyuman kecil". Namun pada penerjemahan frasa tersebut terdapat penambahan kata "di wajahnya". Hal ini dimaksudkan untuk menyampaikan pesan singkat atau konsep yang coba disampaikan oleh penerjemah dari BSu ke dalam BSa. Agar penerjemahan tersebut lebih berterima dan dapat dipahami dengan baik oleh para pembaca.

2. (Data 17)

\begin{tabular}{|c|c|c|c|}
\hline Bahasa sasaran & Hal/baris & Bahasa sumber & $\begin{array}{l}\text { Hal/ } \\
\text { baris }\end{array}$ \\
\hline $\begin{array}{l}\text { Tangan satunya } \\
\text { berpegang pada tali tas } \\
\text { yang tergantung di } \\
\text { bahunya. }\end{array}$ & $24 / 10$ & علدها الأخرى تمسك الخزام المعلق & $25 / 2$ \\
\hline
\end{tabular}

Penerjemahan dia atas menggunakan teknik ekspansi. Dapat dilihat bahwa frasa washfi diterjemahkan menjadi "tali tas yang tergantung”. Kata الحزام المعلق dalam kamus berarti "tali"35 dan kata المعلق berarti "yang tergantung"36. Dan secara harfiah berarti "tali yang tergantung". Namun pada penerjemahan frasa tersebut terdapat penambahan kata "tas". Hal ini dimaksudkan untuk menyampaikan pesan singkat atau konsep yang coba disampaikan oleh penerjemah dari BSu ke dalam BSa. Agar penerjemahan tersebut lebih berterima dan dapat dipahami dengan baik oleh para pembaca.

33 Warson, Ahmad Munawwir, 85.

34 Warson, Ahmad Munawwir, 779.

35 Warson, Ahmad Munawwir, 260.

36 Warson, Ahmad Munawwir, 964. 
3. (Data 18)

\begin{tabular}{|c|c|c|c|}
\hline Bahasa sasaran & Hal/baris & Bahasa sumber & Hal/baris \\
\hline $\begin{array}{l}\text { Tubuhnya meregang di } \\
\text { atas jok mobil yang } \\
\text { empuk. Menganggap } \\
\text { bahwa mata Tuhan tidak } \\
\text { melihatnya. }\end{array}$ & $296 / 13$ & متصتورا أن عين الله في الأريكة الطرية، & $245 / 14$ \\
\hline
\end{tabular}

Penerjemahan dia atas menggunakan teknik ekspansi. Dapat dilihat bahwa frasa washfi diterjemahkan menjadi “jok mobil yang empuk”. Kata الأريكة الطرية dalam kamus berarti "sofa/tempat duduk panjang bersandar"37 dan kata الطرية berarti "empuk"38. Dan secara harfiah maka berarti "sofa yang empuk". Namun pada penerjemahan frasa tersebut terdapat penambahan kata "mobil" tanpa merubah makna dari frasa itu sendiri. Hal ini Agar penerjemahan tersebut lebih jelas dan mudah dipahami oleh pembaca Bsa.

4. (Data 19)

\begin{tabular}{|l|c|r|c|}
\hline \multicolumn{1}{|c|}{ Bahasa sasaran } & $\begin{array}{c}\text { Hal/b } \\
\text { aris }\end{array}$ & Bahasa sumber & Hal/baris \\
\hline $\begin{array}{l}\text { Perempuan melihatnya } \\
\text { sebagai laki-laki yang } \\
\text { terhormat, luar biasa, } \\
\begin{array}{l}\text { sangat baik, serta tidak } \\
\text { ada tandingannya. }\end{array}\end{array}$ & $117 / 1$ & نراد الواحدة منهن رجلا عظيما عبقريا & \\
\hline
\end{tabular}

Penerjemahan dia atas menggunakan teknik ekspansi. Dapat dilihat bahwa frasa washfi diterjemahkan menjadi “laki-laki yang terhormat, luar biasa, sangat baik".

Kata رجال dalam kamus berarti "laki-laki"39 dan kata عظيما berarti "yang terhormat"40, serta kata عبقريا yang berarti "luar biasa pandai”41. Dan secara harfiah maka berarti "laki-laki yang

37 Warson, Ahmad Munawwir, 19.

38 Warson, Ahmad Munawwir, 851.

39 Warson, Ahmad Munawwir, 479.

40 Warson, Ahmad Munawwir, 947.

41 Warson, Ahmad Munawwir, 890. 
terhormat, luar biasa pandai". Namun pada penerjemahan frasa tersebut terdapat penambahan kata "sangat baik" tanpa merubah makna dari frasa itu sendiri. Hal ini dimaksudkan untuk menyampaikan pesan singkat atau konsep yang coba disampaikan oleh penerjemah dari BSu ke dalam BSa. Bahwa laki-laki tersebut adalah orang yang luar biasa dihormati. Agar penerjemahan tersebut lebih berterima dan dapat dipahami dengan baik oleh para pembaca.

\section{E. Teknik Transposisi}

Teknik transposisi merupakan teknik penerjemahan yang mengubah bentuk gramatikal bahasa sumber kedalam bahasa sasaran. Misalnya seperti perubahan bentuk dari jamak kepada bentuk mufrad atau sebaliknya, struktur na'at-man'ut dalam bahasa sumber menjadi struktur man'ut-na'at dalam bahasa sasaran, atau kata kerja atau fi'il menjadi bentuk kata benda atau isim.. Hal ini dapat terjadi karena adanya perbedaan struktur bahasa sumber dengan bahasa sasaran. Berikut merupakan terjemahan yang menggunakan teknik transposisi :

1. (Data 20)

\begin{tabular}{|c|c|c|c|}
\hline Bahasa sasaran & Hal/baris & Bahasa sumber & Hal/baris \\
\hline $\begin{array}{l}\text { Guru-guru, dan staf } \\
\text { pergutuan tinggi berjalan } \\
\text { dalam satu langkah. }\end{array}$ & $19 / 8$ & والمدارس والجامعات، يسيرون بخطوة & $21 / 5$ \\
\hline
\end{tabular}

Dari penerjemahan di atas, jika menggunakan teknik penerjemahan harfiah maka akan diperoleh kata خطوة yang berarti "langkah"42 dan kata واحدة yang berarti "satu”43. Sehingga jika diterjemahkan secara harfiah maka akan menjadi "langkah yang satu". Tetapi dalam penerjemahan ini, penerjemah menggantikan struktur gramatikal BSu pada kata خطوة yang merupakan man'ut menjadi na'at dalam BSa. Begitu juga dengan kata واحدة yang merupakan na'at pada BSu menjadi bentuk man'ut pada BSa. Sehingga terjemahan frasa washfi tersebut menjadi "satu langkah". Hal ini dilakukan supaya hasil terjemahan menjadi lebih baik dan tepat sehingga akan mudah diterima oleh pembaca sasaran dalam memahaminya.

42 Warson, Ahmad Munawwir, 353.

43 Warson, Ahmad Munawwir, 1542. 
2. (Data 21)

\begin{tabular}{|c|c|c|c|}
\hline Bahasa sasaran & Hal/baris & Bahasa sumber & Hal/baris \\
\hline $\begin{array}{l}\text { Guru-guru, dan staf } \\
\text { pergutuan tinggi berjalan } \\
\text { dalam satu langkah } \\
\text { dengan kaki telanjang } \\
\text { yang kesakitan, sepatu } \\
\text { yang berkilau. }\end{array}$ & $19 / 9$ & لاحعدة المدارس والمامعات، يسيرون بخطوة & $21 / 6$ \\
\hline
\end{tabular}

Dari penerjemahan di atas, kata حذاء merupakan jamak taksir dari kata حذاء yang berarti "sepatu"44 dan kata لامعة yang berarti "yang berkilau"45. Sehingga jika diterjemahkan secara harfiah maka akan menjadi "sepatu-sepatu yang berkilau". Tetapi dalam penerjemahan ini, penerjemah menggantikan bentuk gramatikal $\mathrm{BSu}$ yang berupa jamak taksir yaitu yang berarti “sepatu-sepatu” menjadi bentuk mufrad dalam BSa. Sehingga terjemahan frasa washfi tersebut menjadi "sepatu yang berkilau".

3. (Data 22)

\begin{tabular}{|c|c|c|c|}
\hline Bahasa sasaran & Hal/baris & Bahasa sumber & Hal/baris \\
\hline $\begin{array}{l}\text { Tidurlah, Mageeda. Tuhan } \\
\text { kita telah memberikan } \\
\text { banyak kebaikan. }\end{array}$ & $36 / 7$ & كثير يا بجيدة، ربنا أعطاك خير & $34 / 15$ \\
\hline
\end{tabular}

كثير خير dari penerjemahan di atas, kata kamus berarti "kebaikan"46 dan kata

berarti "banyak"47. Sehingga jika diterjemahkan secara harfiah maka akan menjadi "kebaikan yang banyak". Namun dalam penerjemahan ini, penerjemah menggantikan stuktur gramatikal BSu pada kata خير yang merupakan man'ut menjadi na'at dalam BSa.

Begitu juga dengan kata كثير yang merupakan na'at pada BSu menjadi bentuk man'ut pada

BSa. Sehingga terjemahan frasa washfi tersebut menjadi "banyak kebaikan". Hal ini terjadi karena adanya perbedaan struktur sifat dan yang disifati antara BSu dan Bsa dan agar hasil

44 Warson, Ahmad Munawwir, 248.

45 Warson, Ahmad Munawwir, 1288.

46 Warson, Ahmad Munawwir, 378.

47 Warson, Ahmad Munawwir, 1192. 
terjemahan menjadi lebih baik dan tepat sehingga akan mudah diterima oleh pembaca sasaran dalam memahaminya.

4. (Data 23)

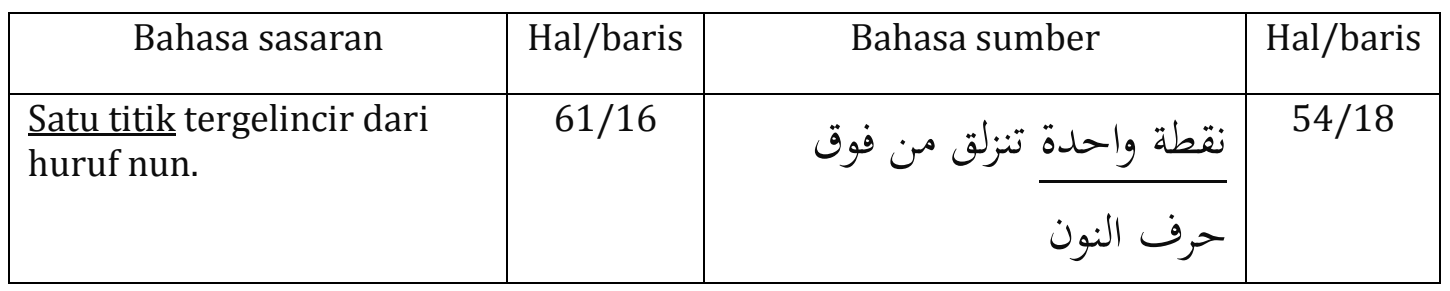

واحدة Dari penerjemahan di atas, kata نقطة damus berarti "titik"48 dan kata berarti "satu"49. Sehingga jika diterjemahkan secara harfiah maka akan menjadi "titik satu". Namun dalam penerjemahan ini, penerjemah mengganti stuktur gramatikal BSu pada kata واحدة yang ولقطة yang merupakan man'ut menjadi na'at dalam BSa. Begitu juga dengan kata merupakan na'at pada BSu menjadi bentuk man'ut pada BSa. Sehingga terjemahan frasa washfi tersebut menjadi "satu titik". Hal ini terjadi karena adanya perbedaan struktur sifat dan yang disifati antara BSu dan Bsa, serta agar penerjemahan lebih berterima dan mudah dipahami.

5. (Data 24)

\begin{tabular}{|l|c|r|c|}
\hline \multicolumn{1}{|c|}{ Bahasa sasaran } & Hal/baris & Bahasa sumber & Hal/baris \\
\hline $\begin{array}{l}\text { Sang dokter berputar dan } \\
\text { melilit sekitar tema itu } \\
\text { dengan pertanyaan yang } \\
\text { berbeda. }\end{array}$ & $108 / 9$ & يدور الطبيب ويلف حول الموضوع & \\
\hline
\end{tabular}

Kata سؤال merupakan jamak taksir dari kata الأسئلة yang berarti “pertanyaaan”50 dan kata المختلفة yang berarti “yang berbeda"51. Sehingga jika diterjemahkan secara harfiah maka akan menjadi "pertanyaan-pertanyaan yang berbeda". Tetapi dalam penerjemahan ini, penerjemah mengganti bentuk gramatikal BSu yang berupa jamak taksir yaitu الأسئلة yang

48 Warson, Ahmad Munawwir, 1546.

49 Warson, Ahmad Munawwir, 1542.

50 Warson, Ahmad Munawwir, 600.

51 Warson, Ahmad Munawwir, 363. 
berarti "pertanyaan-pertanyaan" menjadi bentuk mufrad dalam penerjemahan BSa.

Sehingga terjemahan frasa washfi tersebut menjadi "pertanyaan yang berbeda".

\section{F. Teknik Sinonimi}

Teknik sinonimi merupakan teknik penerjemahan yang menggunakan kata-kata yang memiliki arti mendekati dalam bahasa sumber agar lebih mudah dipahami dan lebih berterima pada bahasa sasaran. Berikut merupakan terjemahan yang menggunakan teknik sinonimi :

1. (Data 25)

\begin{tabular}{|l|c|c|c|}
\hline \multicolumn{1}{|c|}{ Bahasa sasaran } & Hal/baris & Bahasa sumber & Hal/baris \\
\hline $\begin{array}{l}\text { Kedua bola matanya yang } \\
\text { hitam menyala dengan } \\
\text { cahaya biru. }\end{array}$ & $4 / 6$ & تتقد الشعلتان السوداوان بنار زرقاء & تئساء \\
\hline
\end{tabular}

Dalam penerjemahan frasa washfi di atas, penerjemah menerjemahkan نار زرقاء dengan "cahaya biru". Jika diterjemahkan secara harfiah maka kata نار berarti "api”52 dan kata زرقاء berarti "biru"53. Sehingga jika diterjemahkan secara urut akan menjadi "api biru". Tetapi dalam penerjemahan di atas, penerjemah menerjemahkan kata نار dengan "cahaya". Karena penggunaan kata "cahaya" lebih mudah dipahami dan lebih berterima pada bahasa sasaran.

2. (Data 26)

\begin{tabular}{|l|c|r|c|}
\hline \multicolumn{1}{|c|}{ Bahasa sasaran } & Hal/baris & Bahasa sumber & Hal/baris \\
\hline $\begin{array}{l}\text { Kenikmatan tersembunyi } \\
\text { menjalar dari telapak kaki } \\
\text { ke betisnya. }\end{array}$ & $16 / 15$ & قدمة خفية كانت تسري من بطن إلى ساقها & \\
\hline
\end{tabular}

لذة خفية Dalam penerjemahan frasa washfi di atas, penerjemah menerjemahkan dengan "kenikmatan tersembunyi". Jika diterjemahkan secara harfiah maka kata لذة berarti "kesenangan"54 dan kata خفية berarti "tersembunyi"55. Sehingga menjadi "kesenangan tersembunyi". Namun dalam penerjemahan di atas, penerjemah

52 Warson, Ahmad Munawwir, 1474.

53 Warson, Ahmad Munawwir, 568.

54 Warson, Ahmad Munawwir, 1246.

55 Warson, Ahmad Munawwir, 357. 
menerjemahkan kata لذة dengan "kenikmatan". Dari penerjemahan tersebut, maka telah diketahui bahwa penerjemah menggunakan teknik penerjemahan sinonimi, yaitu menggunakan kata-kata yang memiliki arti mendekati dalam bahasa sumber.

3. (Data 27)

\begin{tabular}{|l|c|c|c|}
\hline \multicolumn{1}{|c|}{ Bahasa sasaran } & Hal/baris & Bahasa sumber & Hal/baris \\
\hline $\begin{array}{l}\text { Di atas pintu terdapat } \\
\text { tempelan yang berkilau } \\
\text { dari tembaga. }\end{array}$ & $16 / 15$ & فوق الباب رقعة لامعة من النحاس & \\
\hline
\end{tabular}

رقعة لامعة

dengan "tempelan yang berkilau". Jika diterjemahkan secara harfiah maka kata رقعة berarti

"tambalan”56 dan kata لامعة berarti "yang berkilau"57. Sehingga jika diterjemahkan secara urut akan menjadi "tambalan yang berkilau". Tetapi dalam penerjemahan di atas, penerjemah menerjemahkan kata رقعة dengan "tempelan". Dari penerjemahan tersebut, maka telah diketahui bahwa penerjemah menggunakan teknik penerjemahan sinonimi, yaitu menggunakan kata-kata yang memiliki arti mendekati dalam bahasa sumber.

4. (Data 28)

\begin{tabular}{|l|l|r|l|}
\hline \multicolumn{1}{|c|}{ Bahasa sasaran } & Hal/baris & Bahasa sumber & Hal/baris \\
\hline $\begin{array}{l}\text { Mageeda al Khartiti } \\
\text { membayarnya dengan upah } \\
\text { kecil untuk menulisakannya } \\
\text { beberapa artikel. }\end{array}$ & $331 / 3$ & تدفع له بحيدة الخرتيتي راتبا صغيرا & \\
\hline
\end{tabular}

Kata راتبا dalam kamus berarti "gaji"58 dan kata صغير berarti "kecil”59. Sehingga secara

harfiah frasa tersebut berarti "gaji kecil”. Namun oleh penerjemah, kata راتبا diterjemahkan menjadi "upah". Karena kata tersebut lebih mudah dipahami dan lebih berterima dibanding kata "gaji" pada bahasa sasaran.

56 Warson, Ahmad Munawwir, 522.

57 Warson, Ahmad Munawwir, 1288.

58 Warson, Ahmad Munawwir, 470.

${ }^{59}$ Warson, Ahmad Munawwir, 779. 
5. (Data 29)

\begin{tabular}{|l|c|c|c|}
\hline \multicolumn{1}{|c|}{ Bahasa sasaran } & Hal/baris & Bahasa sumber & Hal/baris \\
\hline $\begin{array}{l}\text { Aku pergi ke psikiater, teman } \\
\text { lama ayahku dari sekolah } \\
\text { dulu. }\end{array}$ & $135 / 25$ & $\frac{115 / 20}{\text { ذهبت إلى الطبيب النفسي المبيك في المدرسة }}$ & \\
\hline
\end{tabular}

Pada penerjemahan di atas, secara harfiah frasa washfi

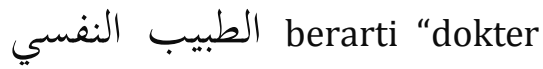
jiwa"60. Namun oleh penerjemah, frasa tersebut diterjemahkan menjadi "psikiater". Karena kata tersebut lebih mudah dipahami dan lebih berterima dibanding kata "dokter jiwa" pada bahasa sasaran.

\section{G. Teknik Modulasi}

Teknik modulasi, yaitu teknik yang memberikan padanan yang berbeda sudut pandang, perspektif maupun menyangkut perubahan maknawi yang lain secara semantik. Perbedaan antara teknik modulasi, sinonimi, dan ekspansi adalah teknik modulasi memberikan padanan yang berbeda sudut pandang pada bahasa sasaran, sedangkan teknik sinonimi menggunakan kata yang memiliki makna yang dekat sebagai padanan pada bahasa sasaran. Kemudian, teknik ekspansi adalah memperluas makna pada bahasa sasaran agar lebih mudah dipahami. Berikut merupakan terjemahan yang menggunakan teknik modulasi :

1. (Data 30)

\begin{tabular}{|c|c|c|c|}
\hline Bahasa sasaran & Hal/baris & Bahasa sumber & Hal/baris \\
\hline $\begin{array}{l}\text { Remaja teladan yang } \\
\text { rasa cintanya kepada } \\
\text { Tuhan mengalir dalam } \\
\text { pikiran, tubuh, dan } \\
\text { rohnya. }\end{array}$ & $18 / 20$ & 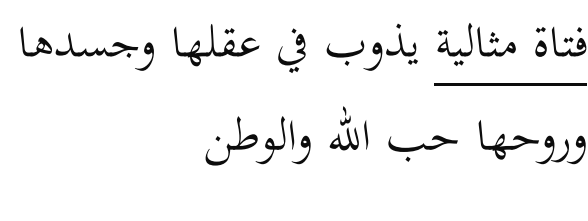 & $20 / 20$ \\
\hline
\end{tabular}

Secara harfiah, kata فتاة dalam kamus berarti "gadis/anak perempuan"61 dan kata مثالية

yang berarti "teladan"62. Sehingga berarti "gadis yang teladan". Tetapi dalam penerjemahan ini, penerjemah menerjemahkan kata فتاة menjadi "remaja". Sehingga terdapat pergeseran

60 Warson, Ahmad Munawwir, 836.

61 Warson, Ahmad Munawwir, 1034.

62 Warson, Ahmad Munawwir, 1309. 
makna dalam BSu yang menggunakan makna khusus ke dalam makna umum yang tidak spesifik untuk perempuan pada BSa, yang kemudian frasa washfi tersebut diterjemahkan menjadi "remaja teladan".

2. (Data 31)

\begin{tabular}{|l|c|c|c|}
\hline \multicolumn{1}{|c|}{ Bahasa sasaran } & Hal/baris & Bahasa sumber & Hal/baris \\
\hline $\begin{array}{l}\text { Kedua bola matanya yang } \\
\text { hitam menyala dengan } \\
\text { cahaya biru. }\end{array}$ & $4 / 5$ & تتقد الشعلتان السوداوان بنار زرقاء & \\
\hline
\end{tabular}

Kata الشعلة merupakan bentuk mutsanna dari kata berarti "nyala api”63 dan kata السوداوان yang berarti "dua hitam". Sehingga secara harfiah berarti "dua nyala api hitam". Tetapi oleh penerjemah, kata menerjemahkan الشعلتان diterjemahkan dengan "kedua bola mata". Sehingga terjadi pergeseran makna antara BSu dengan BSa, karena kedua kata tersebut memilki makna yang berbeda yang kemudian frasa washfi tersebut diterjemahkan menjadi "kedua bola mata yang hitam".

3. (Data 32)

\begin{tabular}{|c|c|c|c|}
\hline Bahasa sasaran & Hal/baris & Bahasa sumber & Hal/baris \\
\hline $\begin{array}{l}\text { Ia berhenti di depan } \\
\text { bangunan besar. }\end{array}$ & $48 / 15$ & تأمام باب العماراة العالية وقفت & $44 / 19$ \\
\hline
\end{tabular}

Secara harfiah, kata العماراة yang berarti "bangunan" dan kata العالية yang berarti “tinggi”64. Namun oleh penerjemah kata العالية diterjemahkan menjadi "besar". Sehingga terjadi pergeseran makna dalam BSu ketika diterjemahkan ke dalam BSa.

4. (Data 33)

\begin{tabular}{|l|c|r|c|}
\hline \multicolumn{1}{|c|}{ Bahasa sasaran } & Hal/baris & Bahasa sumber & Hal/baris \\
\hline $\begin{array}{l}\text { Ibu Maryam tinggal dalam } \\
\text { bangunan kecil yang } \\
\text { terdiri dari dua kamar. }\end{array}$ & $62 / 24$ & أبلة مريم كانت تعيش فس شقة & \\
\hline
\end{tabular}

63 Warson, Ahmad Munawwir, 726.

64 Warson, Ahmad Munawwir, 969. 
Pada penerjemahan dia atas, kata شقة dalam kamus berarti “apartemen"65 dan kata صغيرة yang berarti "kecil”66. Sehingga secara harfiah berarti "apartemen kecil. Namun oleh penerjemah, kata شقة diterjemahkan menjadi "bangunan". Sehingga terjadi pergeseran makna dalam BSu yang menggunakan makna khusus ke dalam makna umum pada BSa.

5. (Data 34)

\begin{tabular}{|c|c|c|c|}
\hline Bahasa sasaran & $\mathrm{Hal} /$ baris & Bahasa sumber & Hal/baris \\
\hline $\begin{array}{l}\text { Salah satu dari mereka } \\
\text { berjalan di bawah sinar } \\
\text { matahari menghirup } \\
\text { udara segar. }\end{array}$ & $239 / 1$ & تمشي الواحد أو الواحدة منهم تحت الشمس في الهواء الطلق & $199 / 14$ \\
\hline
\end{tabular}

Frasa washfi المواء الطلق pada kalimat di atas, diterjemahkan menjadi "udara yang segar". Sedangkan secara harfiah, kata الهواء berarti "udara"67 dan kata الطلق berarti "terbuka"68. Sehingga berarti "udara terbuka". Namun oleh penerjemah kata الطلق diterjemahkan menjadi "segar". Sehingga terjadi pergeseran makna dalam BSu ketika diterjemahkan ke dalam BSa. Hal ini agar frasa tersebut lebih berterima dan mudah dipahami.

\section{H. Teknik Naturalisasi}

Teknik naturalisasi, yaitu teknik membentuk kata baru dalam bahasa dengan cara mengambil bunyi dalam bahasa sumber. Pembentukaan ini dilakukan setelah bunyi tersebut disesuaikan dengan sistem bunyi dan ejaan dalam bahasa sasaran. Teknik ini identik dengan penerjemahan fonologis. Berikut merupakan terjemahan yang menggunakan teknik naturalisasi:

1. (Data 35)

\begin{tabular}{|l|c|c|c|}
\hline \multicolumn{1}{|c|}{ Bahasa sasaran } & Hal/baris & Bahasa sumber & Hal/baris \\
\hline $\begin{array}{l}\text { Cologne mousturized dari } \\
\text { Paris. }\end{array}$ & $147 / 2$ & 124/15 & \\
\hline
\end{tabular}

65 Warson, Ahmad Munawwir, 733.

66 Warson, Ahmad Munawwir, 779.

67 Warson, Ahmad Munawwir, 1527.

68 Warson, Ahmad Munawwir, 862. 
الكولونيا المستورد Dalam penerjemahan frasa washfi di atas, penerjemah menerjemahkan dengan "cologne mousturized". Dari penerjemahan tersebut, penerjemah menggunakan teknik naturalisasi, karena mengambil frasa washfi الكولونيا المستورد dalam BSu dan kemudian menerjamhkannya dalam BSa dengan menyesuaikan sistem bunyi dan ejaan. Hal ini dimaksudkan agar penerjemahan tersebut dapat berterima dan terbaca oleh pembaca bahasa sasaran.

2. (Data 36)

\begin{tabular}{|l|c|r|c|}
\hline \multicolumn{1}{|c|}{ Bahasa sasaran } & Hal/baris & Bahasa sumber & $\begin{array}{c}\text { Hal/bari } \\
\text { s }\end{array}$ \\
\hline $\begin{array}{l}\text { Dialah tangan } \\
\text { kanannya, } \\
\text { menyimpan alamat } \\
\text { dan nomor telepon } \\
\text { mereka dalam notes } \\
\text { kecil. }\end{array}$ & $268 / 11$ & ومن ملكت اليمين، يكفظ عناوينهن & \\
\hline
\end{tabular}

Dalam penerjemahan frasa washfi di atas, penerjemah menerjemahkan نوتة صغيرة dengan "notes kecil". Dari penerjemahan tersebut, penerjemah menggunakan teknik naturalisasi. Karena kata نوتة pada frasa washfi tersebut, diterjemahkan dengan "notes" yang merupakan kata yang dibentuk dari BSu dengan menyesuaikan sisitem bunyi dan ejaan pada Bsa. Hal ini agar penerjemahan tersebut dapat berterima dan terbaca oleh pembaca bahasa sasaran.

\section{Teknik Parafrase}

Teknik Parafrase, yaitu teknik penerjemahan yang memberikan penjelasan tambahan atau penjelasan makna yang lebih detail yang tidak terdapat pada bahasa sumber dalam bahasa sasaran. Berikut merupakan terjemahan yang menggunakan teknik parafrase :

1. (Data 37)

\begin{tabular}{|c|c|c|c|}
\hline Bahasa sasaran & Hal/baris & Bahasa sumber & Hal/baris \\
\hline $\begin{array}{l}\text { Buku-buku berisi } \\
\text { tentang sastra pada } \\
\text { masa pra Islam. }\end{array}$ & $98 / 5$ & بما فيها ذلك الكتاب عن الأدب & $84 / 3$ \\
\hline
\end{tabular}


Pada penerjemahan frasa washfi di atas, penerjemah menerjemahkan

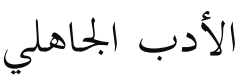

dengan "sastra pada masa pra islam". Sehingga pada penerjemahan tersebut, penerjemah menggunakan teknik parafrase, yaitu dengan memberikan penjelasan tambahan pada BSa.

Karena kata dalam kamus berarti “jahiliyah”69, namun penerjemah menerjemahkan kata tersebut dengan "masa pra Islam". Sehingga terjemahan tersebut menjelaskan makna dari kata "jahiliyah" itu sendiri.

\section{J. Teknik Terjemahan Lazim}

Terjemahan lazim merupakan teknik penerjemahan yang memberikan sebuah istilah yang sudah lazim digunakan baik dalam kamus maupun bahasa sasaran sebagai padanan dari teks bahasa sumber. Berikut adalah data yang menggunakan teknik terjemahan lazim :

1. (Data 38)

\begin{tabular}{|l|l|r|l|}
\hline \multicolumn{1}{|c|}{ Bahasa sasaran } & Hal/baris & Bahasa sumber & Hal/baris \\
\hline $\begin{array}{l}\text { Tubuh Ahmad ad } \\
\text { Damhiri merenggang di } \\
\text { mobil mewahnya, di atas } \\
\text { jok belakang yang }\end{array}$ & $254 / 18$ & يرتخي جسد أحمد الدامهيري في السيارة الفاخرة، فوق الأريكة الخلفية & \\
empuk. & & $\underline{\text { الوثيرة }}$ & \\
\hline
\end{tabular}

Pada penerjemahan di atas, penerjemah menerjemahkan الأريكة الخلفية الوثيرة menjadi

“jok belakang yang empuk”. Sedangkan secara harfiah الأريكة berarti "sofa (tempat duduk panjang dengan sandaran)"70 dan kata الخلفية berarti “yang di belakang"71, serta kata الوثيرة berarti "empuk"72. Namun karena kata الأريكة berada dalam konteks tempat duduk dalam kendaraan, sehingga diterjemahkan dengan "jok". Karena kata "jok" lebih lazim digunakan dalam bahasa sasaran daripada sofa.

${ }^{69}$ Warson, Ahmad Munawwir, 220.

70 Warson, Ahmad Munawwir, 19.

71 Warson, Ahmad Munawwir, 362.

72 Warson, Ahmad Munawwir, 1536. 
2. (Data 39)

\begin{tabular}{|c|c|c|c|}
\hline Bahasa sasaran & Hal/baris & Bahasa sumber & Hal/baris \\
\hline $\begin{array}{l}\text { Pulpen itu bergerak } \\
\text { dalam guncangan di } \\
\text { atas lembaran putih. }\end{array}$ & $254 / 18$ & يتحرك في اهتزازات فوق الصفحة البيضاء & \\
\hline
\end{tabular}

Pada penerjemahan di atas, penerjemah menerjemahkan الصفحة البيضاء menjadi “lembaran putih". Sedangkan secara harfiah الصفحة berarti "halaman buku"73 dan kata البيضاء berarti "putih"74. Namun oleh penerjemah, kata الصفحة diterjemahkan menjadi “halaman" karena kata tersebut sudah lazim digunakan dalam bahasa sehari-hari pada BSa.

3. (Data 40)

\begin{tabular}{|c|c|c|c|}
\hline Bahasa sasaran & Hal/baris & Bahasa sumber & Hal/baris \\
\hline $\begin{array}{l}\text { Beberapa perempuan } \\
\text { berani maju menjadi ibu } \\
\text { angkat jutaan anak yang } \\
\text { tidak sah. }\end{array}$ & $382 / 19$ & تقدمات بعض النسوة من الأمهات & $215 / 20$ \\
\hline
\end{tabular}

Pada penerjemahan di atas, penerjemah menerjemahkan الأمهات النائباتmenjadi “ibu angkat”. Sedangkan secara harfiah الأمهات berarti “ibu-ibu”75 dan kata النائبات berarti "pengganti"76. Namun oleh penerjemah, kata النائبات diterjemahkan menjadi "angkat" karena kata tersebut sudah lazim digunakan dalam bahasa sehari-hari pada BSa dibanding kata "pengganti".

\section{Penilaian Kualitas Frasa Washfi pada Novel Zeina}

Data dalam penelitian ini merupakan data objektif yang bersifat primer. Data tersebut merupakan satuan lingual berupa frasa washfi yang kemudian akan dibagikan kepada 25 responden yang menjadi pembaca target dalam penelitian ini yaitu, mahasiswa bahasa dan sastra Arab Universitas Ahmad Dahlan 14 responden, Alumni mahasiswa bahasa dan sasra Arab Universitas Ahmad Dahlan 1 responden, Mahasiswa bahasa dan sastra Arab UIN Sunan Kalijaga 1

\footnotetext{
73 Warson, Ahmad Munawwir, 780.

74 Warson, Ahmad Munawwir, 124.

75 Warson, Ahmad Munawwir, 39.

76 Warson, Ahmad Munawwir, 1473.
} 
responden, Mahasiswa bahasa dan sastra Arab Universitas Gadjah Mada 1 responden, Mahasiswa pendidikan bahasa Arab Universitas Muhammadiyah Malang 1 responden, Mahasiswa pendidikan bahasa Arab Universitas Muhammadiyah Yogyakarta 2 responden. Dengan kriteria sebagai berikut:

1. Mahasiswa dengan minimal semester 5 .

2. Sudah mengambil mata kuliah teori terjemahan.

3. Sudah mengambil/menguasai ilmu nahwu dan sharaf dengan baik.

4. Menguasai bahasa Indonesia dan Arab dengan baik.

Adapun cara penilaian oleh pembaca/responden, peneliti memberikan 40 data berupa teks BSu dan Bsa yang terhimpun dari 10 teknik terjemahan. Kemudian responden diminta untuk menilai dengan skor 3, 2, atau 1 pada kolom keberterimaan dan keterbacaan. Skor 3 menunjukkan penerjemahan tersebut berterima dan tingkat keterbacaan mudah, skor 2 menunjukkan penerjemahan tersebut kurang berterima dan tingkat keterbacaan sedang, skor 1 menunjukkan penerjemahan tersebut tidak berterima dan tingkat keterbacaan sulit. Berikut merupakan penilaian kualitas penerjemahan frasa washfi pada novel Zeina.

\section{A. Teknik Penerjemahan Harfiah}

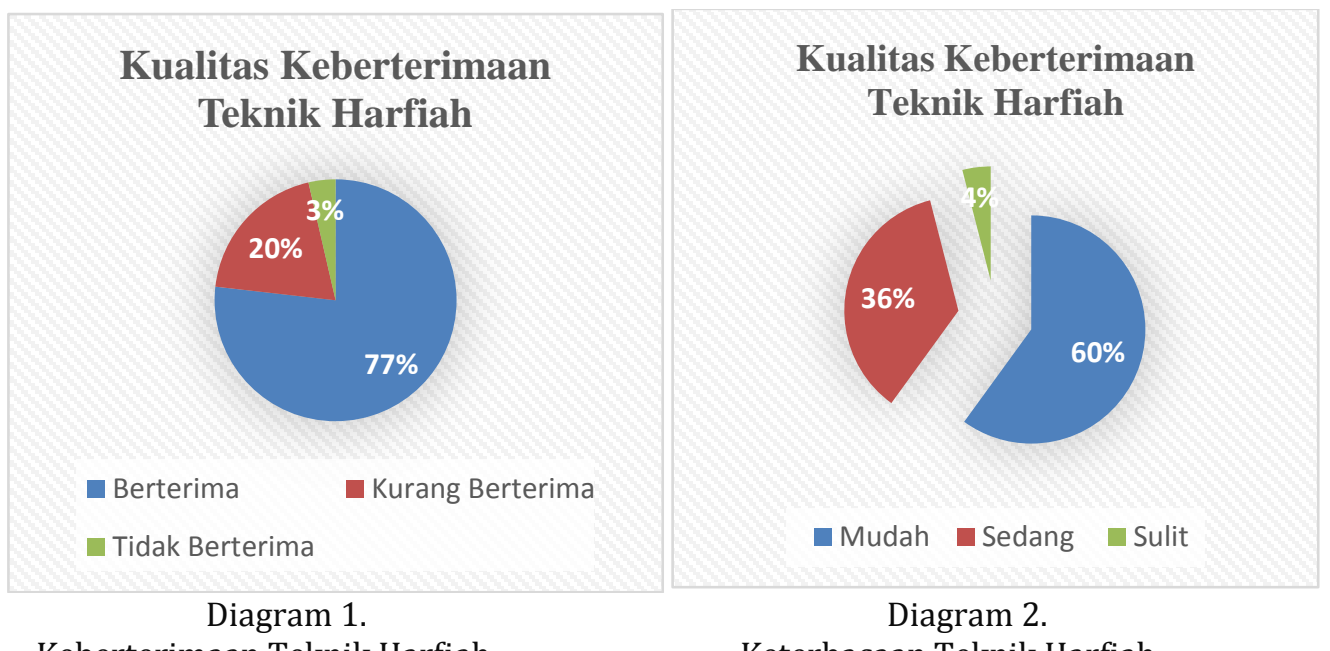

Keberterimaan Teknik Harfiah

Keterbacaan Teknik Harfiah 


\section{B. Teknik Transferensi}

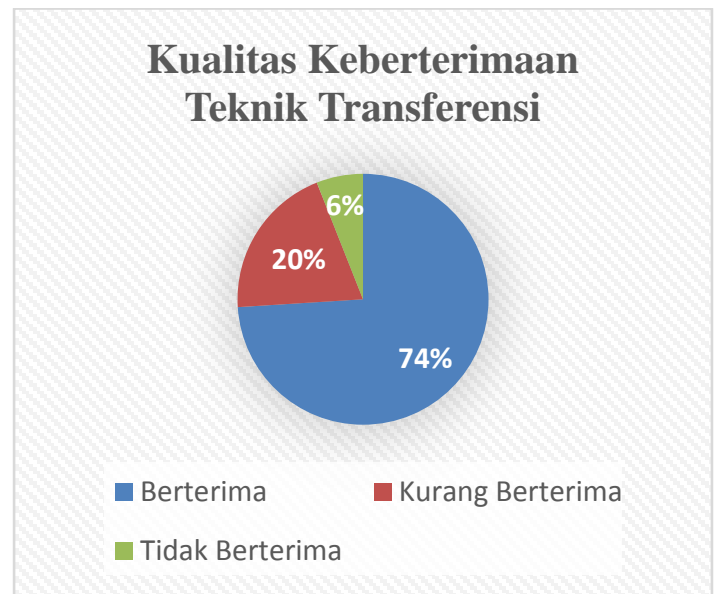

Diagram 1.

Keberterimaan Teknik Transferensi

\section{Kualitas Keterbacaan \\ Teknik Transferensi}

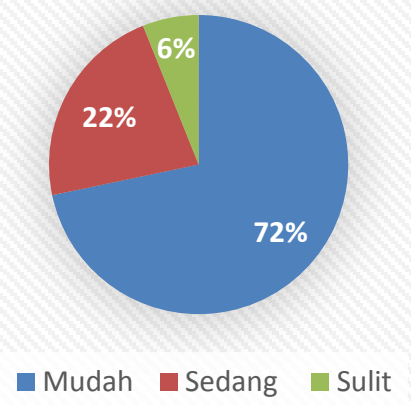

Diagram 2.

Keterbacaan Teknik Transferensi

\section{Teknik Reduksi}

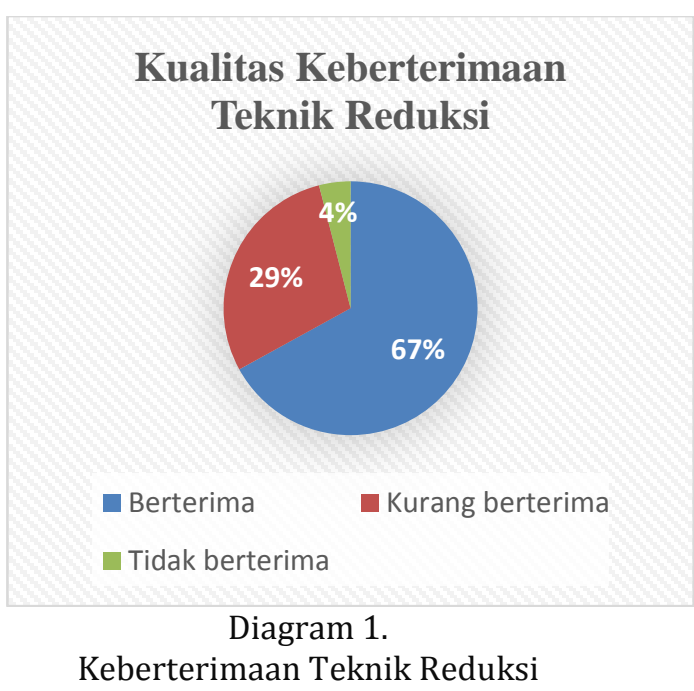

Keberterimaan Teknik Reduksi

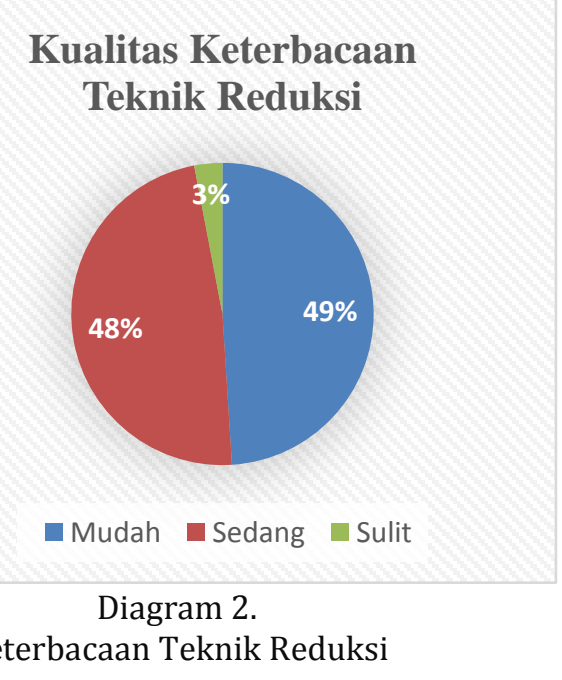

Keterbacaan Teknik Reduksi 


\section{Teknik Ekspansi}

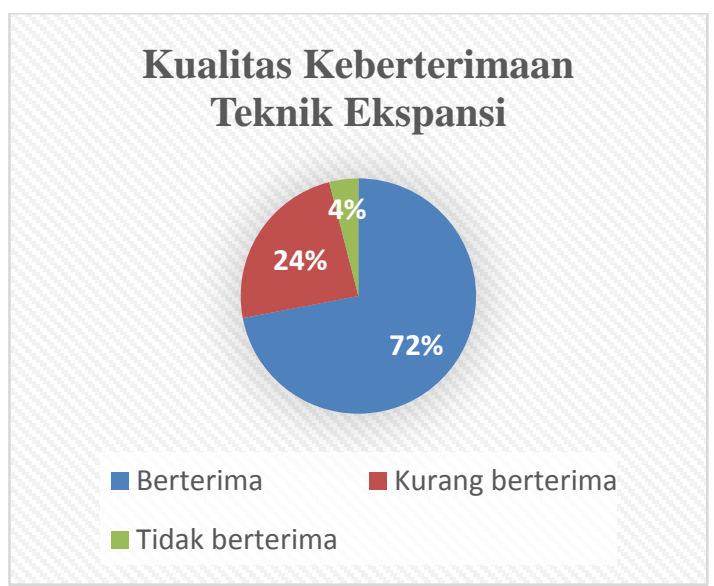

Diagram 1.

Keberterimaan Teknik Ekspansi

\section{Kualitas Keterbacaan}

Teknik Ekspansi

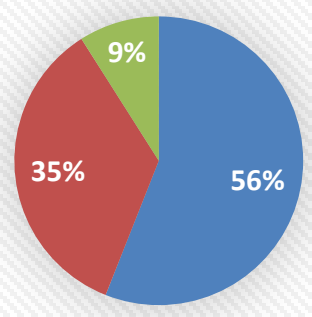

- Mudah Sedang Sulit

Diagram 2.

Keterbacaan Teknik Ekspansi

E. Teknik Transposisi

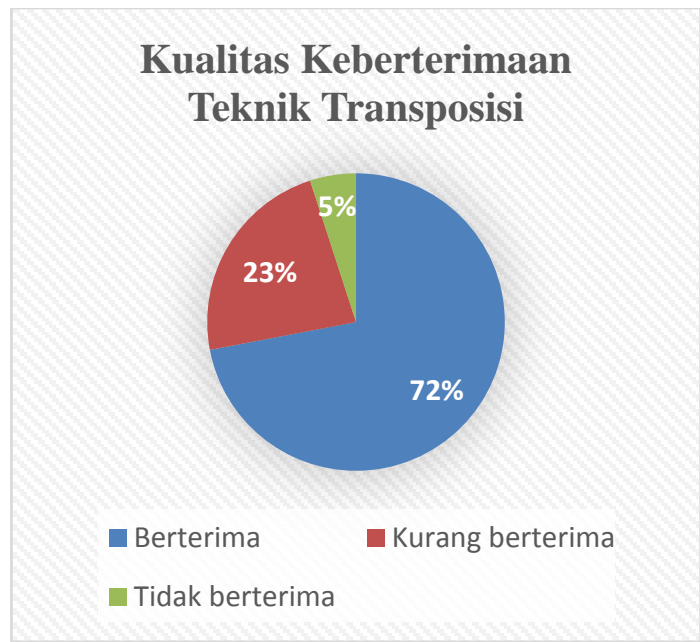

$$
\text { Diagram } 1 .
$$

Keberterimaan Teknik Transposisi

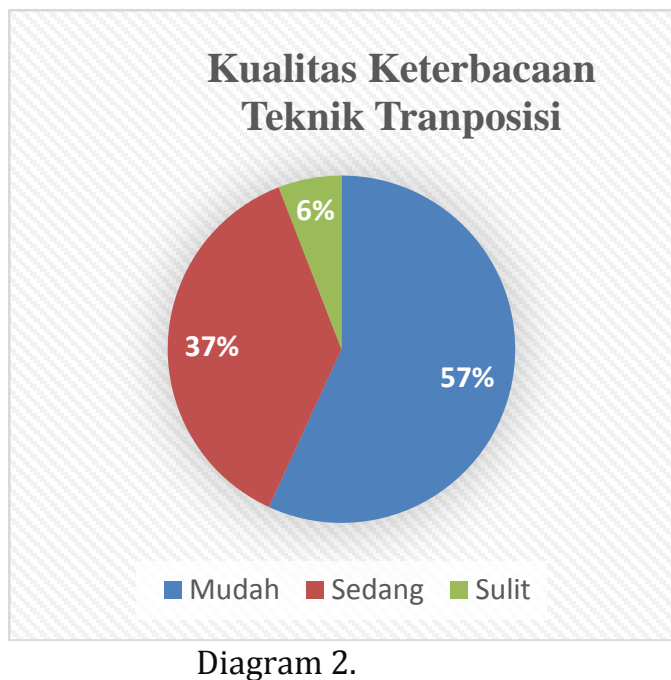

Diagram 2.

Keterbacaan Teknik Transposisi 


\section{F. Teknik Sinonimi}

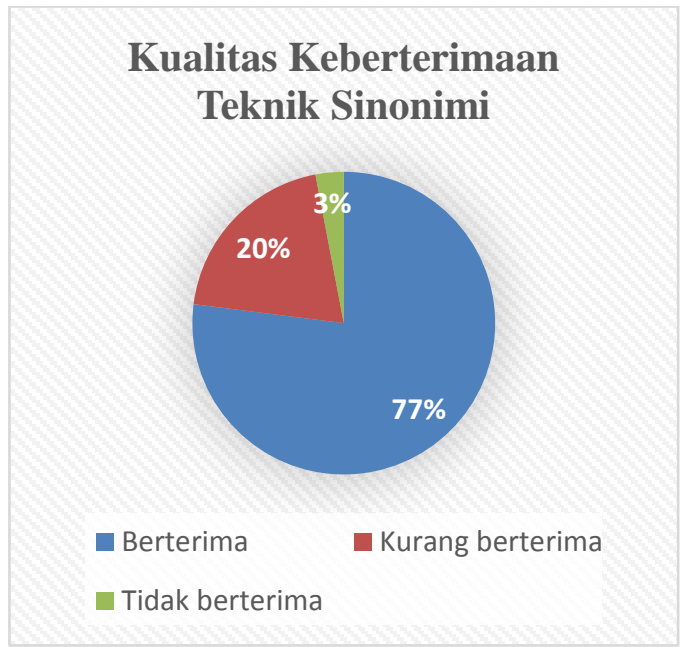

Diagram 1.

Keberterimaan Teknik Sinonimi

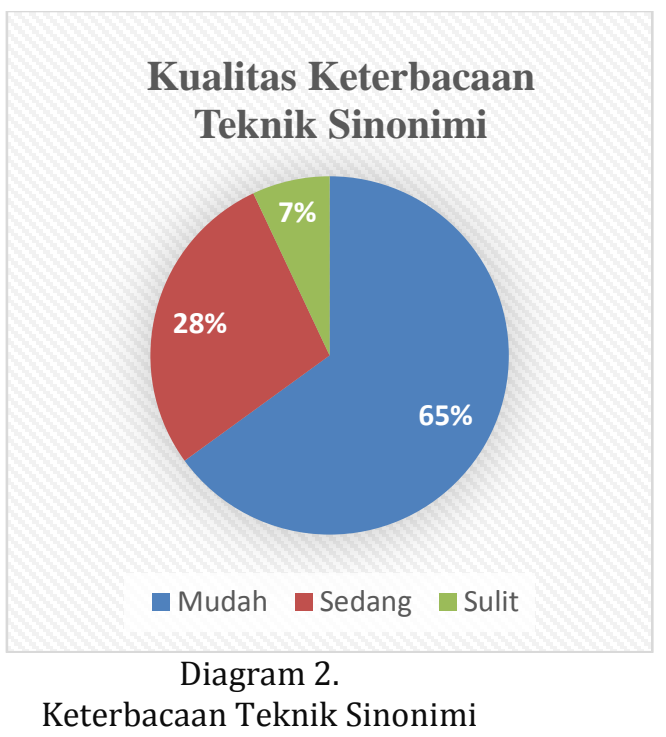

Keterbacaan Teknik Sinonimi

\section{G. Teknik Modulasi}

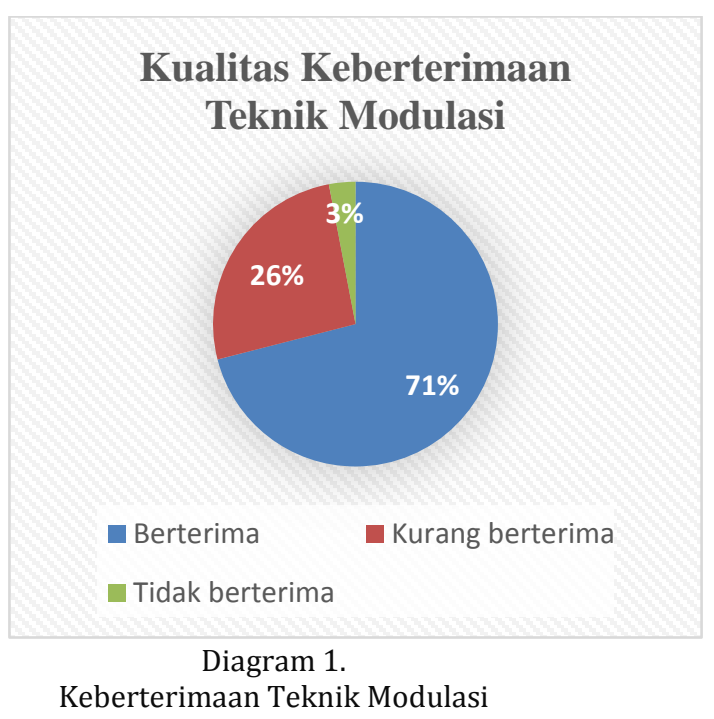

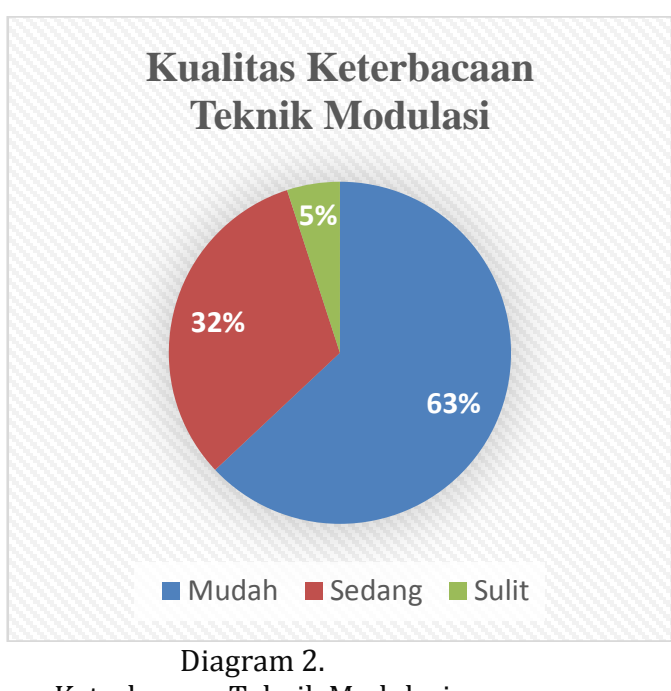

Keterbacaan Teknik Modulasi 
H. Teknik Naturalisasi

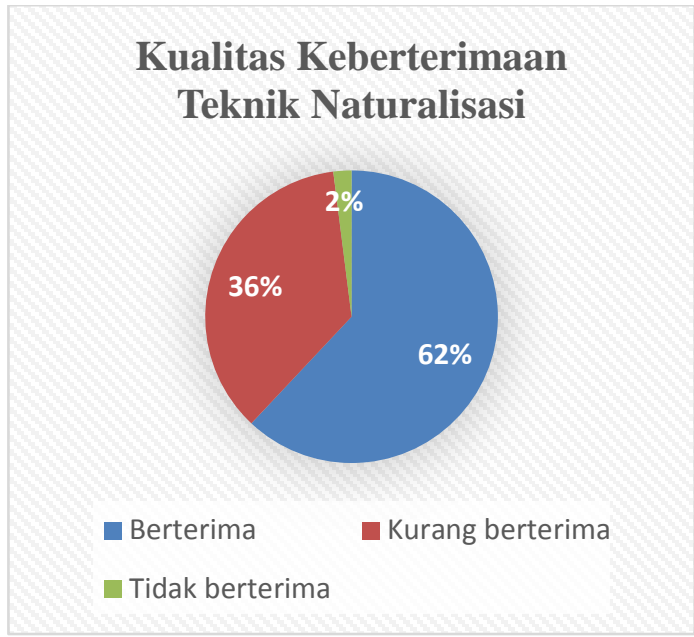

Diagram 1.

Kualitas Keberterimaan Teknik Naturalisasi

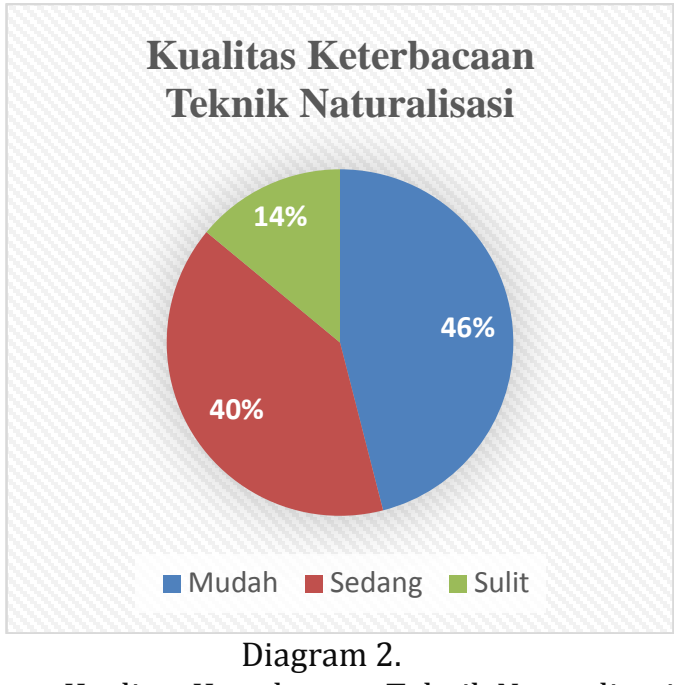

Kualitas Keterbacaan Teknik Naturalisasi

\section{Teknik Parafrase}

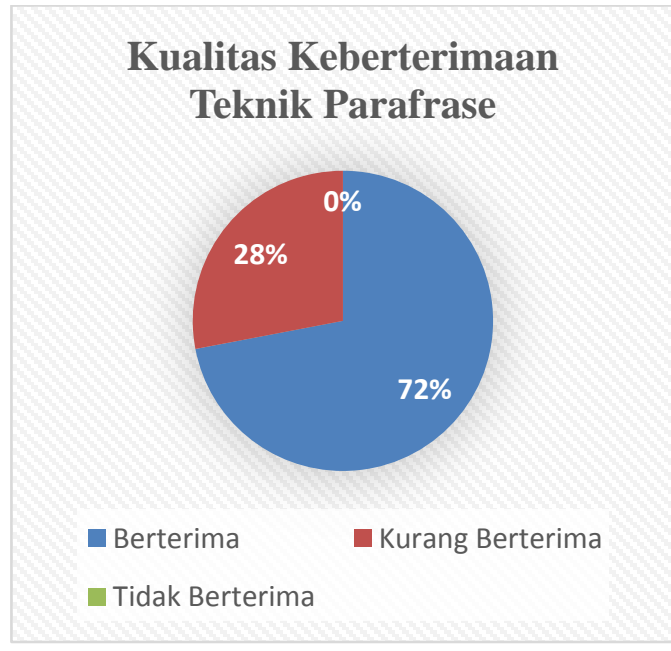

Diagram 1.

Kualitas Keberterimaan Teknik Parafrase

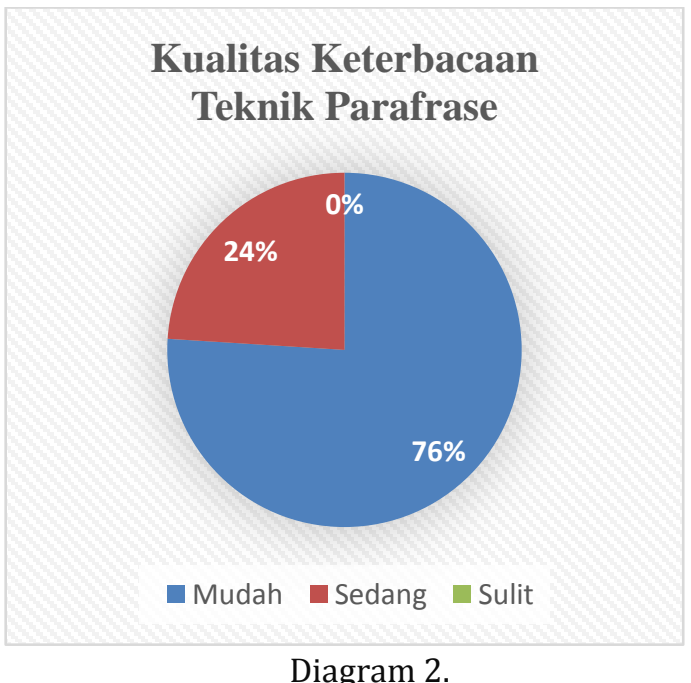

Diagram 2.

Kualitas Keterbacaan Teknik Parafrase 


\section{J. Teknik Terjemahan Lazim}

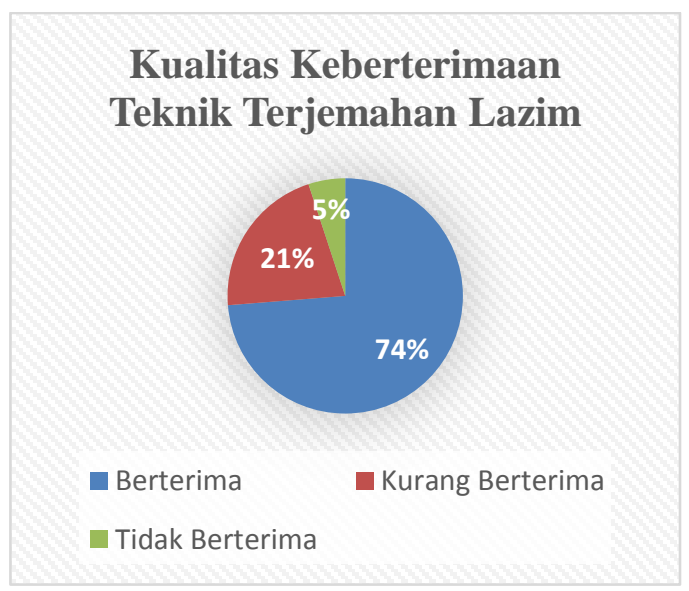

Diagram 1. Kualitas Keberterimaan Teknik Terjemahan Lazim

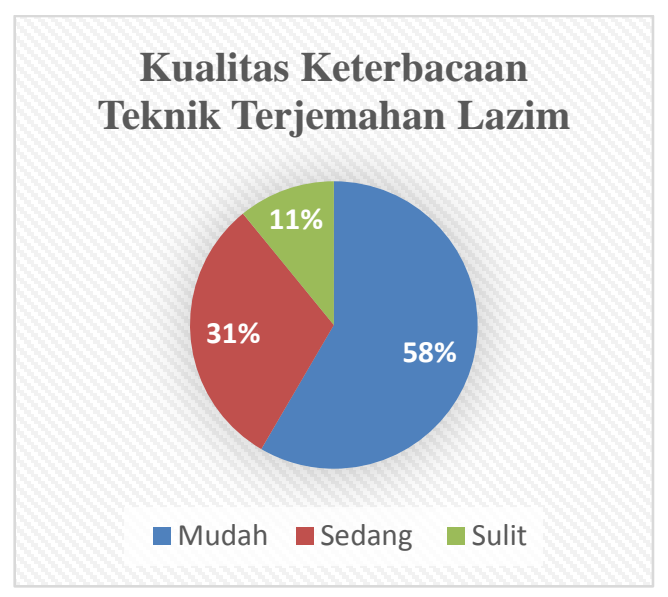

Diagram 1. Kualitas Keterbacaan Teknik Terjemahan Lazim

\section{Kesimpulan}

Dari analisis yang telah dipaparkan oleh peneliti di atas, maka dapat ditarik kesimpulan sebagai berikut:

1. Pada penelitian ini didapatkan 348 data frasa washfi pada novel Zeina dan yang dijadikan sampel data pada penelitian adalah 40 data frasa washfi. Pada penelitian ini juga didapatkan 10 teknik penerjemahan menurut Newmark. Teknik-teknik penerjemahan tersebut adalah sebagai berikut: 1) Teknik penerjemahan harfiah, 2) teknik transferensi, 3) teknik reduksi, 4) teknik ekspansi, 5) teknik transposisi, 6) teknik sinonimi, 7) teknik modulasi, 8) teknik naturalisasi, 9) teknik parafrase, 10) teknik terjemahan lazim. Dan teknik yang paling sering digunakan oleh penerjemah adalah teknik penerjemahan harfiah.

2. Pada penelitian ini diketahui bahwa kualitas penerjemahan frasa washfi yang paling berterima adalah teknik penerjemahan harfiah dan sinonimi, yaitu 77\%, kemudian teknik transferensi dan teknik terjemahan lazim, yaitu 74\%, teknik ekspansi, transposisi dan parafrase $72 \%$, teknik modulasi $71 \%$, teknik reduksi $67 \%$, dan teknik naturalisasi $62 \%$. Kemudian untuk kualitas keterbacaan yang paling mudah/tinggi adalah pada teknik parafrase, yaitu 76\%, teknik transferensi $72 \%$, teknik sinonimi $65 \%$, teknik modulasi $63 \%$, teknik penerjemahan harfiah $60 \%$, teknik terjemahan lazim dan transposisi 58\%, teknik ekspansi 56\%, teknik reduksi 49\%, dan teknik naturalisasi 46\%. 


\section{Daftar Pustaka}

Akmaliyah. Teori \& Praktik Terjemah Indonesia - Arab. Depok: Kencana, 2017.al Ghulayaini, Mhushthafa. Jami'u al Durus al 'Arabiyah. Beirut: al Maktabah al'Ashriyah, 1994.

Alzuhdy ,Yosa Abduh. "Analisis Translation Shift dalam Penerjemahan Bilingual Bahasa Inggris - Bahasa Indonesia." Diksi 2, no. 22 (2014).

Ambarastuti ,Retno Dewi. “Analisis Teknik Penerjemahan Teks Cerita Rakyat Jepang Nezumi No Sumo ke dalam Bahasa Indonesia Tikus dan Sumo pada Situs www.Jitco.or.jp." Jurnal Linguistik Terapan 8, no. 1 (2018).

Andriani, Asna. "FRASA DALAM BAHASA ARAB (Konstruksi Frasa Dalam Bahasa Arab Berdasarkan Unsur Kata Pembentuknya." JURNAL CENDEKIA 2, no. 1 (2016): 103-13.

Fahrurrozi, Andri Wicaksono. Sekilas Tentang Bahasa Indonesia: Catatan mengenai kebijakan bahasa, kaidah ejaan, pembelajaran sastra, penerjemahan dan BIPA. Yogyakarta: Garudhawaca, 2016.

Hidayatullah, Moch Syarif. Cakrawala Linguistik Arab. Jakarta: Grasindo, 2017. Ikhsanto, Nur Eko, and Abdul Malik. "Teknik, Metode, dan Ideologi

Penerjemahan Dalam Terjemahan Buku Risalah Ila Syababil-Ummah."

Jurnal CMES 9, no. 1 (2016).

Ilmi. Bahasa Arab Dasar: Kelas Mutsanna Level 2. Kedua. Jawa Barat: Edu Publisher, 2020.

Kadaruddin. Translation Skill. Yogyakrta: Deepublish, 2016.

Kamal, M. Syaiful. "Perbedaan Struktur Kata Sifat dalam Bahasa Indonesia dengan Bahasa Arab." LISANUNA: Jurnal Ilmu Bahasa Arab dan Pembelajarannya 8, no. 2 (2019): 184-93.

Karyaningsih,Tri Yulianty. "Frasa Nomina Endosentris Atributif Berpewatas Adjektiva dalam Bahasa Rusia dan Indonesia: Aplikasi Analisis Kontrastif

dalam Kalimat." Jurnal Linguistik Terapan Politeknik Negri Malang 8, no. 1 (2018).

Kusuma, Tri Mastoyo Jati. Pengantar (Metode) Penelitian Bahasa. Yogyakarta: Carasvatibooks, 2007.

Kusumaryoko, Prayogo. Dwilogi Variasi Gaya Penerjemah: Landasan Teori.

Yogyakarta: Diandra Kreatif, 2017.

Machali, Rochayal. Pedoman Bagi Penerjemah. Jakarta: Grasindo, 2000. Ma'mur Ilzamudin. “Konsep Dasar Penerjemahan: Kajian Teoretis.” Al Qalam

21, no. 102 (2004): 431-58.

Molina, Lucia, Amparo Hurtado Albir. "Translation Techniques Revisited: A Dynamic and Functionalist Approach." Meta: Translators' Journal 47, no. 4 (2002): 498-512.

Muam, Ahmad, Cisya Dewantara Nugraha. Pengantar Penerjemahan. 
Yogyakarta: UGM Press, 2021.

Nababan, Donald J. "Metode, Strategi, Teknik Terjemahan: Sebuah Tinjauan Mendalam." Kongres Linguistik Nasional XII, 3-6 September, 2007.

Nababan, Mangatur, Ardiana Nuraeni, Sumardiono. "Pengembangan Model Penilaian Kualitas Terjemahan." Universitas Sebelas Maret 24, no. 1 (2012): 39-57.

Newmark, Peter. A Textbook of Translation. New York: Prentice Hall International vUIO Ltd, 1988.

Nida, Eugene Albert, Charles Russell Taber. The Theory and Practice of Translation. Leiden: E.J. Brill, 1969.

Nu'mah, Fuad. Mulakhas Qawa'id al Lughah al 'Arabiyah. Beirut: Dar as Tsaqafah al Islmaiyah, 1986.

PB, Tim Redaksi KBBI. Kamus Besar Bahasa Indonesia (Edisi Keempat).

Jakarta: Pusat Bahasa Departemen Pendidikan Nasional, 2008.

R, Mantasiah. Sintaksis Bahasa Makassar (Suatu TinjauanTransfoormasi generatif). Yogyakarta: Deepublish, 2017.

Romadhan, Mahyudin, and Muhammad Yunus Anis. "RAGAM TEKNIK PENERJEMAHAN FRASA NOMINA DALAM NOVEL MAWĀKIBUL-ACHRĀR KARYA AL-KAILANI: SEBUAH

PENDEKATAN TEORI ILMU PENERJEMAHAN ARAB." Jurnal CMES 9, no. 1 (2016): 73-85.

Semiawan, Conny R. Metode penelitian kualitatif. Jakarta: Grasindo, 2010. Sudiati, Vero, Aloys Widyamartaya. Panggilan Menjadi Penerjemah.

Yogyakarta: Pustaka Widyatama, 2005.

Tolinggi, Syindi Oktaviani R. "Struktur Frasa Berdasarkan Persamaan Distribusinya Dengan Golongan Kata Dalam Bahasa Arab." Shaut al Arabiyyah 7, no. 2 (2019): 121-31.

Warsiman. Membumikan Pelajaran Sastra Yang Humanis. Malang: Universitas Brawijaya Press, 2016.

Warson, Ahmad Munawwir. Al-Munawwir: Kamus Arab-Indonesia. Surabaya: Pustaka Progresif, 1997.

Wuryantoro, Aris. Pengantar Penerjemahan. Yogyakarta: Deepublish, 2018. Zaim, Muhammad. Metode penelitian bahasa: Pendekatan struktural. Padang:

FBS UNP Press, 2014.

Zulfian, Muhammad. Bahasa Arab untuk Semua. Jakarta: Gramedia Pustaka Utama, 2018. 
Vol. 4, No. 1, Juni 2021|67-98 